症例

食道・胃境界部の平滑筋腫を併存した食道アカラシアの 1 治験例

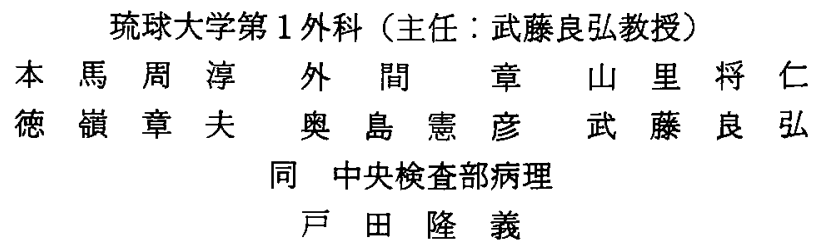

35歳の女性にみられた食道・胃境界部の平滑筋畽を併存した食道アカラシアの 1 例を 報告した。

入院約 3 年前より，燕下障害と上腹部痛を訴えていたか，昭和61年 3 月に他病院で食 道アカランアと診断されて，数回にわたるパルーンによる拡張術を受けた。.てかしなが ら，症状の改善がないために昭和62年 8 月 3 日手術のために紹介入院した。 上部消化管 造影，内視鏡検查拉よび食道内圧測定などで食道アカラシフと診断し，同年 8 月11日に Jekler \& Lhotka 法に準じて手術を行った，手術時に食道・胃境界部に大豆大の結節を 発見し，摘出した。組織学的に，食道のフウェルバッ八神経叢には神経節細胞はなく， 結節は平滑筋腫であった。

食道平滑筋腫を併存したアカラシフは，今をでに報告はなく，自験例が第 1 例と考え られた。

索引用語：食道アカラシア, 食道平滑筋畽

はじめに

食道や胃の平滑筋腫の報告例は近年増加の傾向にあ るが，食道・胃境界部に発生する平滑筋腫はいまだ約 30例の報告を見るにすぎず，平滑筋腫の発生部位とし ては食道・胃境界部は比較的稀な部位といえよう。筆 者らは，食道フカラシアに食道・胃境界部平滑筋腫を 併存した，極めて稀な 1 例を経験したので報告する。

$$
\text { 症例 }
$$

患者：35歳，女性.

主訴：燕下困難，心窩部痛。

家族歴およひ既往歴：特記すべきことなし．

現病歴: 昭和59年11月頃より, 䓵下困難之上腹部痛 などを自覚するよ5になり，昭和61年 3 月には症状の 改善が見られないので，他病院を受診して食道了カラ シアと診断された。 その後, 同病院において数回に及 ぶハルーンによる拡張術を受けたが，症状の改善がな いので, 昭和62年 8 月 3 日に手術のため紹介入院した。 入院時現症：身長 $152.2 \mathrm{~cm}$, 体重 $38 \mathrm{~kg}$ の瘦世型で

1990年 2 月 14 日受付 1990 年 8 月 29 日採用
あったが，理学的には異常所見を認めなかった。

入院時一般検査: 特に異常な所見は見られなかっ た.

上部消化管造影：食道造影ではフラスコ型1)(径5.0 $\mathrm{cm}$ ，II度)を呈していたが，ちなみに昭和61年 3 月は 紡鍾型（径 $3.9 \mathrm{~cm}, \mathrm{II}$ 度), 同年 11 月はフラスコ型 (径 $5.5 \mathrm{~cm}$ ，II 度）の形態を示していた（図 1).

内視鏡検查：食道内腔の拡張は中等度で，長軸の屈 曲はなく，粘膜面も異常は見られなかった。食道・胃 境界部の通過性も良好であって, 同部の粘膜面も正常 であった。

食道内圧测定：静止压は $20 \mathrm{cmH}_{2} \mathrm{O}$ と六進してい て, 内圧分類の B 型を呈した(図 2).メコリールテス トは行わなかった。

以上の検查所見より，アカラシアと診断して同年 8 月11日に手術を施行した。

手術所見：開腹後, 腹部食道を露出して，あらかじ め食道・胃境界部に留置していた小児用 SengstakenBlakemoreチェープを膨らをせて腹部食道に軽度の 緊張をかけた。 そして境界部前壁に食道側へ $6 \mathrm{~cm} の$ ， 

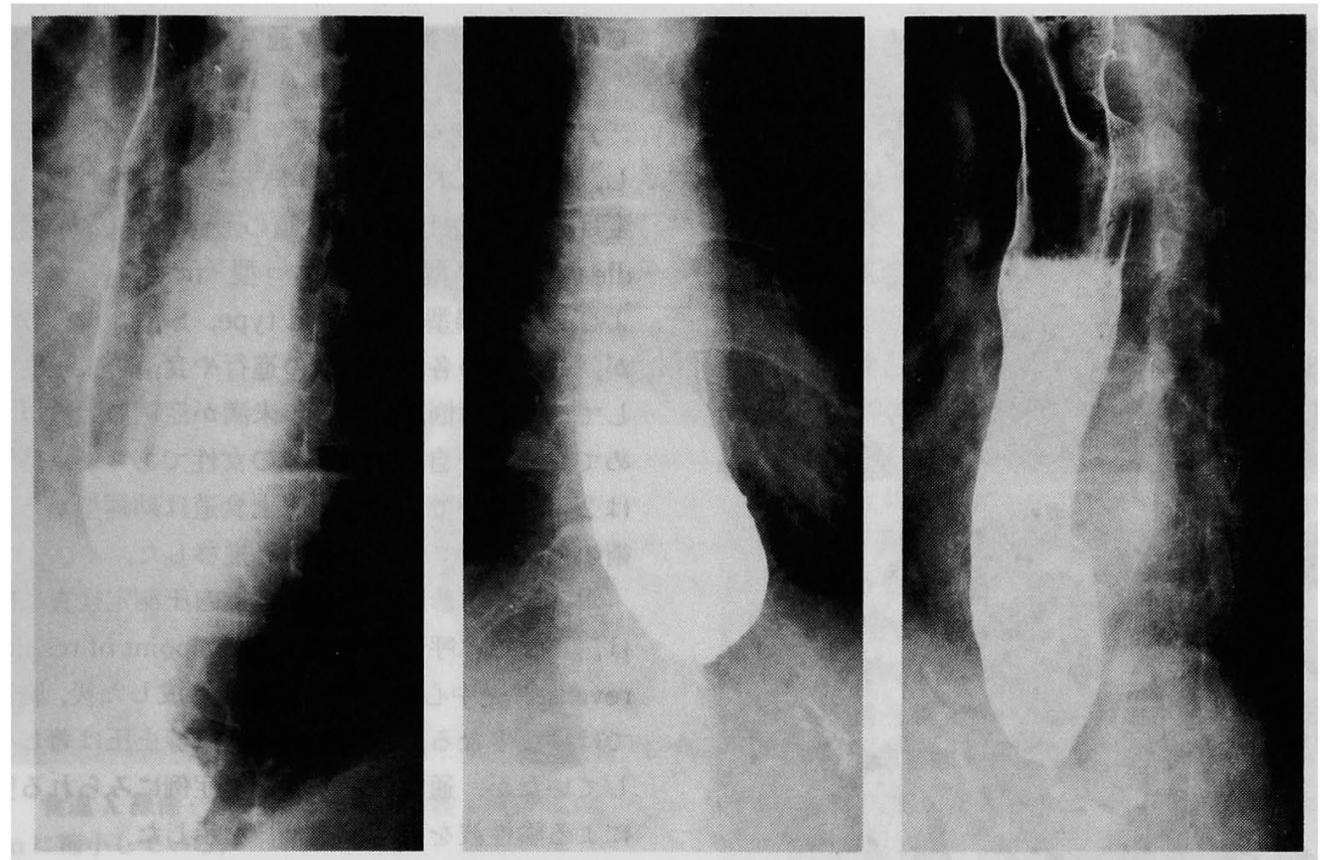

図 1 食道 X 線像：左：昭和 61 年 2 月径 $3.9 \mathrm{~cm}$, 中：同年 11 月径 $5.5 \mathrm{~cm}$, 右：昭和 62 年 8 月径 $5.0 \mathrm{~cm}$
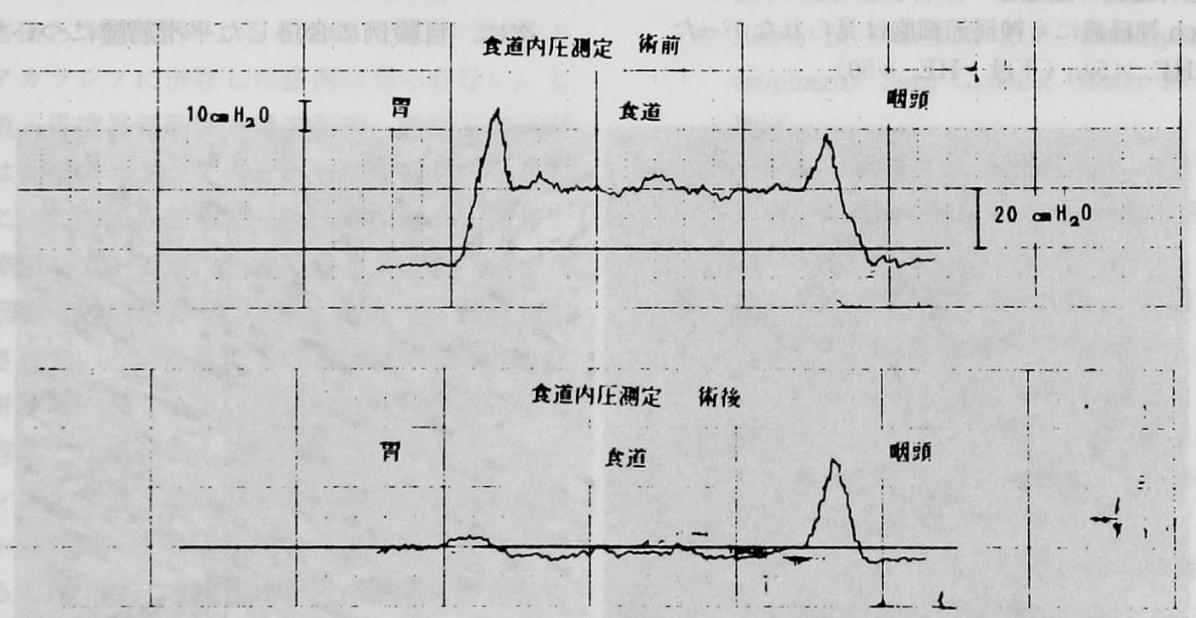

図 2 食道内圧測定検査：術前（上段）と術後（下段）の内圧測定成績を示す.

胃側へ $2 \mathrm{~cm}$ の筇層縦切開を加えた。その際，境界部の 筋層内に軟骨様の大豆大の結節 $(20 \times 7 \times 5 \mathrm{~mm})$ を偶然 発見し摘出した. Jekler \& Lhotka 法")に準じて手術を 行い, 幽門形成を付加した。

組織学的所見：採取した食道小切片の筋層間のアウ エルバッハ神経叢には細胞節細胞はなく(図 3), 軟骨 様結節は平滑笳腫之診断された（図4).
術後経過：術後経過良好で, 第 3 病日より経口摄取 を開始し自覚症状は著しく改善した。第 9 病日の食道 造影検査では，下部食道の径は $2.5 \mathrm{~cm}$ となっていて， 食道・胃境界部の通過も良好であった（図 5 ). その後 の食道内王測定では，下部食道括約筋（LES）の圧は 保たれ，静止内压も胃に対して陰王となった。

術後 1 力月で $1.5 \mathrm{~kg}, 6$ 力月で10kg の体重増加がみ 


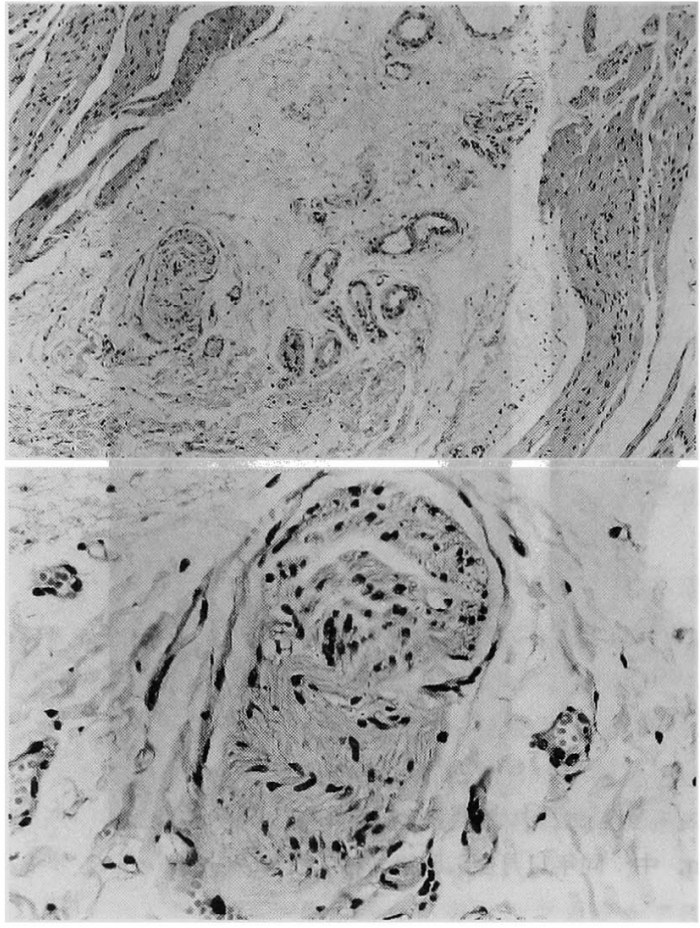

図 3 食道神経叢の組織像：採取した切片のいずれの Auerbach 神経叢にも神経節細胞は見られなかった (上段：HE, ×5)，(下段：HE, ×50).
られ, 術後 2 年半の現在は通常の生活を楽しんでいる。 考案

食道アカラシアの発症年柃は30〜35歳をピークと し，性別では本症は女性にやや多いとされている，病 変は X 線検査上，下部食道の形態により紡錘型 (spindle type, SP 型), フラスコ型 (frask type, F 型) お よび S 状結腸型（sigmoid type, S 型）に分けられる が，これ等の各型は病変の進行や食道の㧪張度と相関 していて, 病悩期間は 5 年末満が症例の半数以上を占 めている314). 自験例は35歳の女性であって, 病悩期間 は 2 年 9 力月であり, X 線上食道は紡錘型から，拡張 術の効果なくフラスコ型へと推移した。

本症の確定診断に結付く食道内圧測定検査に関して は，正常では呼吸相変換点 PRR (point of respiratory reversal)を中心に下部昇圧帯を形成した後, 胸部食道 では陰圧となる，自験例では食道静止圧は著しく上昇 していたが，通常のアカラシア症例にみられる空與下 による陰性波を欠く $\mathrm{B}$ 型315)6)を示した.

本症の外科的治療には様々な術式が用いられている が，筆者らは Jekler \& Lhotka 法に準じた術式を用い て良好な成績を得ている。

次に，自験例に合併した平滑筋腫について検討して

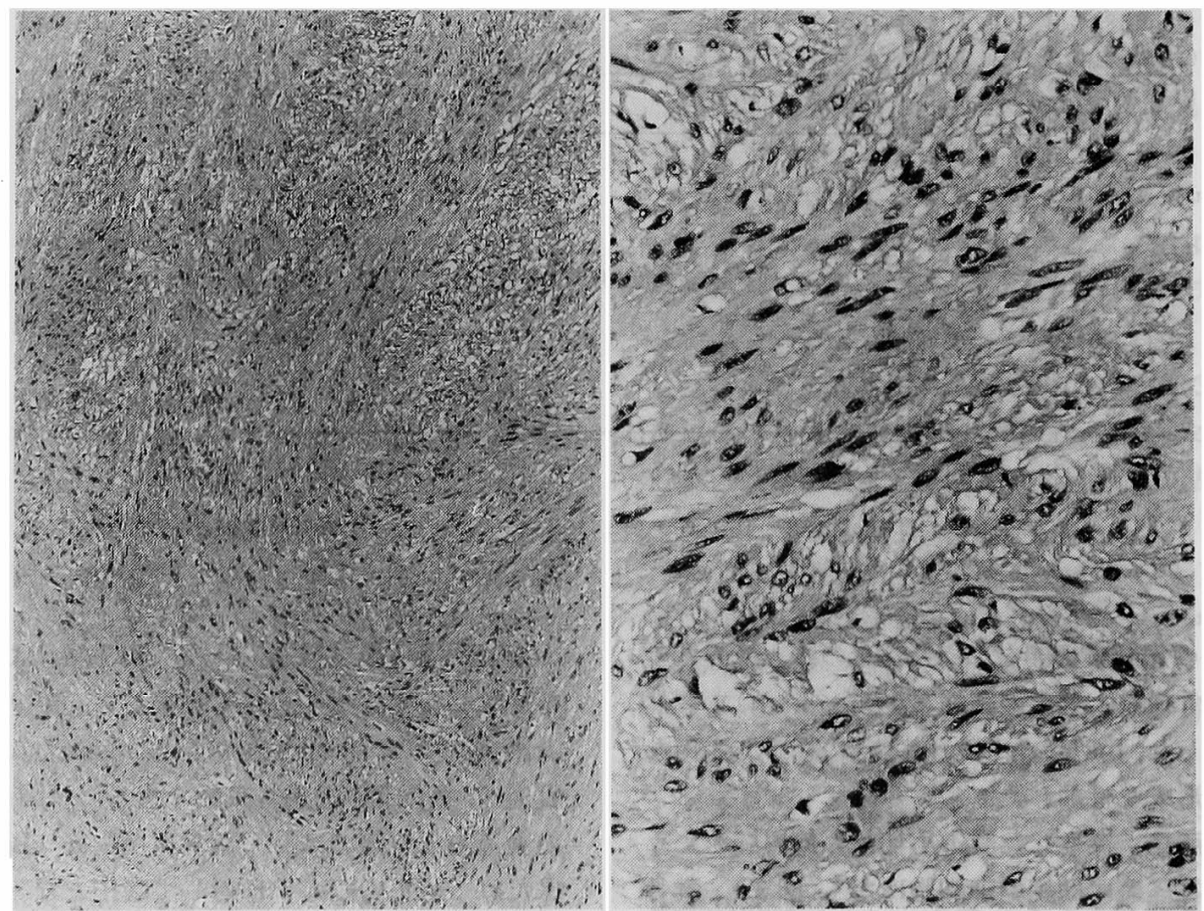

図 4 平滑筋腫の組織像：(左 : HE, $\times 5$ ), (右 : HE, $\times 50)$, 


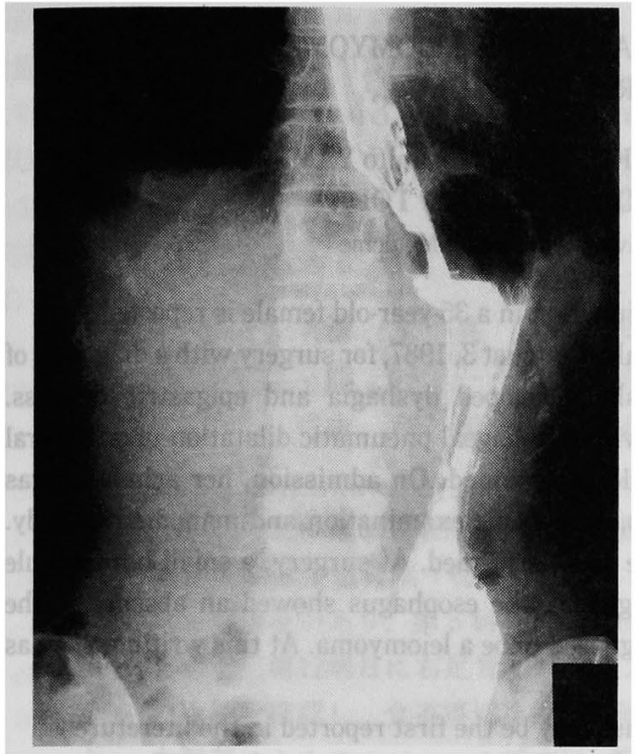

目 5 食道 $\mathbf{X}$ 線像 (術後)：下部食道の最大横径は2.5 $\mathrm{cm}$ に縮小している.

みると，食道・胃境界部に発生した平滑筋腫の本邦報 告例は，吉田ら 少なく、アカラシアに併存した症例は見られない。し かし，食道・胃境界部筋腫の発生年齢，性比，打上び 臨床症状は食道アカラシアのそれらに類似している。 このように，この境界部筋腫は臨床事項においてアカ ラシアに酷似しているが, 食道 X 線および内視鏡検査 で境界部筇腫は特徵的所見 ${ }^{8)}$ を呈するので一般に診断 は容易とされている。それでも，自験例の様に他の食 道疾患と併存し，かつ小さい筇腫である場合は必ずし も診断は容易でないといえよう ${ }^{9110)}$.

アカラシアと食道平滑筋腫との併存例の報告例は見 当たらなかったが，この両疾患の発生年齢と性比が酷 似していることより，自験例は両者が偶然に併存した と考古るのが妥当と思われる.大切なことはアカラシ アに隱れた悪性病変を併存している可能性があるこ と 1112)を留意して診療にあたるべきであろう。
おわりに

35歳の女性にみられた食道・胃境界部の平滑筋腫と 食道アカラシアを併存した稀な症例を報告し，文献的 に考察を加党た。

\section{文献}

1）食道疾患研究会編：食道アカラシア取扱い規約, 金原出版, 1983

2) Jekler J, Lhotka J : Modified heller procedure to prevent postoperative reflux esophagitis in patients with achalasia. Am J Surg 113: 335 $-337,1968$

3）平嶋毅：食道アカラシアの病態と外科的治療, 日消外会誌 $20: 2072-2081,1987$

4）遠藤光夫, 山田明義, 吉田 操他 : 食道アカラシ 了, 逆流性食道炎, 臨と研 $61: 1081-1086,1984$

5）石上浩一 編：外科 Mook, No 33, 食道非癌性疾 患. 金原出版, 1983, p161-178

6）島津久明：食道アカラシフ。臨外 37：1373 $-1378,1982$

7）吉田晃治, 才津秀樹, 野中道泰他：食道・胃境界部 に発生した平滑筋畽の 1 例, 日臨外医会誌 48 ： $226-234,1987$

8) Lewis B, Maxfield RG: Leiomyoma of the esophagus. Surg Gynecol Obstet 99 : 105-128, 1954

9）小林康人, 勝見正治, 河野暢之他：食道平滑筋腫の 3 例一本邦 264 例の分析一, 日臨外医会誌 42 : 169-176, 1981

10）岡本康久，笹原潤治，原藤和泉他：食道の囊状拡張 を伴 5食道胃接合部重複平滑筋腫の 1 治験例, 外 科診療 $26: 789-793,1984$

11）嶺 博之, 中村輝久, 河野俧他：アカラシアに併 存した食道癌の統計的観察, 日胸外会誌 32 : 2041-2047, 1984

12）平嶋 毅, 中林靖明, 磯野可一他：特発性食道払張 症に食道癌を合併した 9 例, 外科 $32: 361-368$, 1970 


\title{
A CASE OF ACHALASIA CONCOMITANT WITH LEIOMYOMA OF THE ESOPHAGOGASTRIC JUNCTION
}

\author{
Kaneatsu HONMA, Akira HOKAMA, Norihiko OKUSHIMA, Masahito YAMAZATO, \\ Fumio TOKUMINE, Yoshihiro MUTO and Takayoshi TODA \\ First Department of Surgery, Ryukyu University School of Medicine
}

A case of achalasia with leiomyoma of the esophagogastric junction in a 35-year-old female is reported.

The patient was admitted to the Ryukyu University Hospital on August 3,1987, for surgery with a diagnosis of achalasia. Approximatery 3 years before this adimission, she developed dyshagia and epigastric distress. Thereafter, she was diagnosed to have achalasia and treated with esophageal pneumatic dilatation upon several occasions, but no evidence of postdilatation improvement could be obtained. On admission, her achalasia was definitely diagnosed by means of upper gastrointestinal series, endoscopic examination and manometric study. Esophagocardiomyotomy through Jekler and Lhotka procedure was performed. At surgery, a small hard nodule within the wall of esophagus was incidentally found. Histologically, the esophagus showed an absence of the ganglion cells in the Auerbach's plexus and the nodule was diagnosed to be a leiomyoma. At this writing, she has been doing well for two and half years after surgery.

A leiomyoma concomitant with achalasia is rare and this case may be the first reported in the litereture. 